\title{
Effects of Date Palm (Phoenix dactylifera) Seed Extract on Heavy Metals Concentrations in Carp (Cyprinus carpio)
}

\author{
Maryam Mohammadi ${ }^{1 *}$, Mehdi Soltani ${ }^{2 * *}$, \\ Amir Siahpoosh $^{3}$, Mehdi Shamsaei Mehrjan ${ }^{1}$
}

\begin{abstract}
${ }^{1}$ Department of Aquaculture, Science and Research Branch, Islamic Azad University, Tehran, Iran ${ }^{2}$ Department of Aquatic Animal Health, Faculty of Veterinary Medicine, University of Tehran, Tehran, Iran ${ }^{3}$ Medicinal Plants Research Center and Department of Pharmacognosy, Faculty of Pharmacy, Ahvaz Jundishapur University of Medical Sciences, Ahvaz, Iran
\end{abstract}

Received: 6 November 2015

Accepted: 18 February 2016

\begin{abstract}
The effects of different doses of date palm (Phoenix dactylifera) seed (DPS) extract on heavy metals $(\mathrm{Pb}, \mathrm{Cd}, \mathrm{As}, \mathrm{Hg})$ concentrations of common carp (Cyprinus carpio) were evaluated. The fish $(31.6 \pm 3.7 \mathrm{~g})$ were assigned to five treatments of three replications each. Five treatments were held using five different DPS extracts at doses of $0 \%$ (control), $0.5 \%, 1 \%, 2 \%$, and $4 \%$. The results revealed that heavy metals concentrations of fish decreased in the $0.5 \%$ and $1 \%$ treatments $(\mathrm{P}<0.05) . \mathrm{Hg}$ and $\mathrm{Cd}$ concentrations in muscle decreased in all treatments $(\mathrm{P}<0.05)$. The results of this research clearly show that the addition of DPS extract to a fish diet has a significant effect on heavy metals concentrations $(\mathrm{P}<0.05)$. DPS extracts were shown to be rich in phenolics and flavonoids. Therefore, they have also been discussed as protectants against heavy metal stress. It could be concluded that feeding common carp a diet enriched with DPS extract could decrease heavy metals concentrations that can cause cancer.
\end{abstract}

Keywords: date palm seed extract, Phoenix dactylifera, Cyprinus carpio, heavy metals concentrations

\section{Introduction}

Heavy metals contamination is a globally recognized public health hazard because these pollutants are widespread in the environment, including marine and freshwater ecosystems, from either natural or anthropogenic sources. As a consequence, they can be accumulated by aquatic organisms through exposure to metals present in water and sediments or in the food chain.

*e-mail: M40_Mohammadi@yahoo.com

**e-mail: msoltani@ut.ac.ir
Thus diet comprises the main route of exposure to these elements in the general population [1].

Some of these elements such as mercury, arsenic, cadmium, and lead have no known role in biological systems. They are natural trace components of the aquatic environment, but their levels have increased due to industrial, agricultural, and mining activities. Even low metal concentrations may threaten the health of aquatic and terrestrial organisms - and people [2].

Date seed is the major byproduct of date fruit. The date seeds constitute approximately $10 \%$ of the fruits. Also, the date seeds contain a high percentage of carbohydrates (81.0-83.1\%), protein $(5.17-5.56 \%)$, 
oil (10.19-12.67\%), ash (1.12-1.15\%), and oleic acid (41.3-47.7\%) [3].

Presently, date seeds are used mainly for animal feed industries. However, given their excellent nutritional profile, value-added utilization of date seed powder has a potential for use in food applications as well. Date seed is a waste product that is generated in huge amounts by the date production process. Date flesh has long been known for its high nutritional value and health benefits [4]. It is also recognized as a rich source of compounds including phenolic acids and flavonoids. Date seeds have also been shown to have excellent nutritional quality due to high amounts of minerals, vitamins, lipids, and protein [5, 13]. Additionally, date seeds contain phenolics and total flavonoids, which have a chelating agent role in contrast to heavy metals accumulation [6].

Fish, meanwhile, is acknowledged as an integral component of a well-balanced diet that provides a healthy source of energy, high-quality proteins, vitamins, and a wide range of other important nutrients [7]. But in contrast to the potential health benefits of dietary fish intake, the chemical pollutants contained in these products have emerged as an issue of concern, particularly for frequent fish consumers [8]. So this study was conducted to investigate the effects of date palm (Phoenix dactylifera) seed extract on the accumulation of heavy metals in fish.

\section{Materials and Methods}

\section{Plant Materials and Preparation of Extract}

The date fruits were collected from Shadegan, Iran, during the last stage of the ripening process in which the dates look dehydrated (the tamar stage), and identified by the Department of Medicinal Plants and Natural Products Research Center, Ahvaz Jundishapur University of Medical Sciences, Ahvaz, Iran. Seeds were isolated from fruits, then soaked in water and washed to remove any remaining date flesh. The seeds were air-dried under the shade at room temperature and ground to convert the seeds to powder. Powdered date seeds were extracted after 72 hours of maceration in methanol. The extract was then concentrated under reduced pressure in a rotary evaporator to reach the desired volume. The solvent was removed using a freeze dryer (operon). The yield of the extract (dry powder) was calculated to be $4.2 \%$.

\section{Fish and Experimental Treatments}

In this study 150 common carp (weighting $31.6 \pm 3.7 \mathrm{~g}$ ) were collected from the Khouzestan Aquaculture Association and transferred to a set of aquariums (15 x 1501 each, including: five aquariums with three replicates for each aquarium and 10 fish in each). The fish were divided randomly into five treatments. Fish were placed for 60 days in aquariums containing decolorized tap water at $26-28^{\circ} \mathrm{C}, \mathrm{pH}$ of $7.8-8.4$, dissolved oxygen level $66-87 \%$ of saturation, concentration of $\mathrm{NO}_{2}^{-}$of 0.02-0.06 mg/dm 3 , and $\mathrm{NH}_{4}^{+} 4.6-7.1 \mathrm{mg} / \mathrm{dm}^{3}$.

Five treatments were held in five different date palm (Phoenix dactylifera) seed extracts at doses of $0 \%$ (control), $0.5 \%, 1 \%, 2 \%$, and $4 \%$. During the study period, three times a day the fish was fed by commercial carp food. The composition figures of the commercial diet (wet basis $\%$ ) were $11 \%$ humidity, $28 \%$ protein, $14 \%$ lipid, and $12 \%$ ash, $1 \%, 3.5 \%$ fiber (feeding rate: $2 \%$ of fish body weight). The water was aerated properly to supply oxygen to water at levels near the saturation level. During the test, physicochemical properties of water such as temperature and oxygen were measured daily. After 60 days, a total of 150 samples of common carp (Cyprinous carpio) were collected from aquariums to determine heavy metals content.

\section{Sample Preparation}

Approximately $0.7 \mathrm{~g}$ of muscle and liver tissues of all fish samples from each treatment were microwavedigested for $30 \mathrm{~min}$ in a closed quartz vessel with $2 \mathrm{~mL}$ of $\mathrm{H}_{2} 0,4 \mathrm{~mL}$ of $\mathrm{HNO}_{3}$, and $0.5 \mathrm{~mL}$ of $\mathrm{HCl}$. The microwave oven was programmed at $1,400 \mathrm{~W}$ and 80 bar as power and pressure limits, respectively (ramp time $10 \mathrm{~min}$; hold time $10 \mathrm{~min}$; cooling time $20 \mathrm{~min}$ ). The digested solution was then transferred to a decontaminated tube for its later analysis. Quartz vessels were vigorously cleaned, soaked for $24 \mathrm{~h}$ in $15 \% \mathrm{HNO}_{3}$, thoroughly rinsed with Milli-Q water before use, and dried at $80^{\circ} \mathrm{C}$ for about $2 \mathrm{~h}[9]$.

\section{Instrumentation}

In order to identify the phenolic profile of DPS extract, phytochemical analysis was done by high-performance liquid chromatography (HPLC) [10]. An AAnalyst 800 atomic absorption spectrometer (Perkin Elmer, Norwalk, USA) equipped with a graphite furnace and an AS-800 autosampler, Zeeman background correction system, and graphite tubes with integrated L'vov platform was used to determine $\mathrm{Pb}$ and $\mathrm{Cd}$. As was measured with direct flow injection through a hydride generation system (Perkin-Elmer FIAS-100) coupled to the AAnalyst 800. Total $\mathrm{Hg}$ was determined in a Perkin Elmer 560 atomic absorption spectrometer (Perkin Elmer, Norwalk, USA) equipped with a power supply lamp system and MHS10 mercury hydride system. Fish samples were subjected to a microwave-assisted digestion procedure (Multiwave 3000, Anton Parr).

\section{Analytical Procedures}

- Pb: A calibration curve $(0,50,100$, and $200 \mu \mathrm{g} / \mathrm{L})$ was prepared in $0.2 \% \mathrm{HNO}_{3}$ and samples were diluted 1:4. Aliquots of $10 \mu \mathrm{L}$ of digested samples were introduced directly into the graphite furnace with an equal volume of matrix modifier $\left(10 \mathrm{~g} / \mathrm{L}\right.$ of $\mathrm{NH}_{4} \mathrm{H}_{2} \mathrm{PO}_{4}$ prepared 
Table 1. Validation of analytical methods.

\begin{tabular}{|c|c|c|c|c|c|c|c|}
\hline Analyte & $\begin{array}{c}\text { Linearity } \\
(\mathrm{R} 2)\end{array}$ & $\begin{array}{c}\text { LOD } \\
(\mathrm{ppm})\end{array}$ & $\begin{array}{c}\text { LOQ } \\
(\mathrm{ppm})\end{array}$ & $\begin{array}{c}\text { Precision } \\
(\mathrm{RSD} \%)\end{array}$ & $\begin{array}{c}\text { Certified } \\
\text { value }(\mathrm{ppb})\end{array}$ & $\begin{array}{c}\text { Observed } \\
\text { value }(\mathrm{ppb})\end{array}$ & $\begin{array}{c}\text { CRM recovery } \\
(\%)\end{array}$ \\
\hline $\mathrm{Pb}$ & 0.9998 & 0.007 & 0.02 & 4.3 & 12 & 11.76 & 98 \\
\hline $\mathrm{Cd}$ & 0.9925 & 0.0011 & 0.0045 & 2.8 & 22 & 21.025 & 95.57 \\
\hline $\mathrm{As}$ & 0.9932 & 0.004 & 0.01 & 3.7 & 29 & 31 & 106.90 \\
\hline $\mathrm{Hg}$ & 0.9999 & 0.001 & 0.002 & 1.6 & 4 & 3.838 & 95.94 \\
\hline
\end{tabular}

in $0.2 \%(\mathrm{v} / \mathrm{v})$ nitric acid and $0.1 \%$ Triton $\mathrm{X}-100)$. A hollow cathode lamp was used.

- Cd: A calibration curve $(0,1,3$, and $5 \mu \mathrm{g} / \mathrm{L})$ was prepared in $0.2 \% \mathrm{HNO}_{3}$ and samples were diluted 1:4. Aliquots of $20 \mu \mathrm{L}$ of digested samples were introduced directly into a graphite furnace with an equal volume of matrix modifier (a mixture of $3.3 \% \mathrm{Pd}$ and $0.03 \% \mathrm{Mg}$ as nitrates in $0.2 \% \mathrm{HNO}_{3}$ ). An electrodeless discharge lamp was used.

- As: The arsenic contained in standard solutions (calibration curve $0,0.5,1.5$, and $2.5 \mu \mathrm{g} / \mathrm{L}$ ) or digested fish samples was reduced to $\mathrm{As}^{3+}$ prior to analysis with a mixture of potassium iodide and ascorbic acid. One milliliter of concentrated $\mathrm{HCl}$ and $1 \mathrm{~mL}$ of $5 \%$ (w/v) KIascorbic acid were added to $1 \mathrm{~mL}$ of digested sample. After $45 \mathrm{~min}$ at room temperature the mixture was diluted to $10 \mathrm{~mL}$ with water. The reducing agent was an aqueous solution of $0.2 \%(\mathrm{w} / \mathrm{v}) \mathrm{NaBH}_{4}$ in a $0.05 \%(\mathrm{w} / \mathrm{v})$ $\mathrm{NaOH}$ solution freshly prepared and filtered. Standard addition was required and cell temperature was set at $900^{\circ} \mathrm{C}$. An electrodeless discharge lamp was used.

- Hg: The mercury standard calibration plot $(0,2.5,5$, and $10 \mu \mathrm{g} / \mathrm{L}$ ) was prepared in $10 \mathrm{~mL}$ of acid mixture containing $1.5 \% \mathrm{HNO}_{3}$ and $1.5 \% \mathrm{H}_{2} \mathrm{SO}_{4}$. Nine $\mathrm{mL}$ of acid mixture was added to $1 \mathrm{~mL}$ of digested sample. Mercury was determined using an aqueous solution of $3 \%(\mathrm{w} / \mathrm{v}) \mathrm{NaBH}_{4}$ in a $1 \%(\mathrm{w} / \mathrm{v}) \mathrm{NaOH}$ solution freshly prepared and filtered as reducing agent. One to two drops of silicone antifoaming was dispensed into a reaction flask before introducing any solution. All solutions were stabilized by adding $500 \mu \mathrm{L}$ of $5 \%$ $\mathrm{KMnO}_{4}$ solution before starting the determination. An electrodeless discharge lamp was used [11].

\section{Statistical Analysis}

Data were reported as mean deviation of triplicate measurements. Significant differences $(p<0.05)$ within means were analyzed by one-way analysis of variance (ANOVA) and Tukey's honestly significant difference (HSD) test in the RStudio Software Version 0.98.1103 [12]. Analytical methods validation parameters including linearity, LOD, LOQ, precision, accuracy, certified value, observed value, and analysis of fish tissue-CRM recovery are shown in Table 1.

\section{Results and Discussion}

Heavy metals concentrations of $\mathrm{Hg}, \mathrm{Cd}, \mathrm{Pb}$, and $\mathrm{As}$ in muscle and liver tissues of fish were fed the $0 \%$ (control), $0.5 \%, 1 \%, 2 \%$, and $4 \%$ of date palm (Phoenix dactylifera) seed (DPS) extract diet after 60 days of culture period (Table 2).

\section{Effects of DPS Extract on Heavy Metals Concentrations of Fish}

$\mathrm{Pb}$ concentrations in fish muscle were decreased in $0.5 \%$ and $1 \%$ of DPS extract treatment than $0 \%$ (control) treatment and in liver were decreased in $0.5 \%, 2 \%$, and $1 \%$ DPS extract treatments than $0 \%$ (control) treatment, respectively, except for $\mathrm{Pb}$ concentrations in muscle and liver of 4\% DPS extract, which were increased in comparison with other treatments. Also, $\mathrm{Pb}$ concentration in muscle of $2 \%$ DPS extract treatment was similar to $4 \%$ DPS extract treatment. A significant difference of $\mathrm{Pb}$ concentration in muscle of 4\% DPS extract treatment was observed compared to $0.5 \%$ and $1 \%$ DPS extract and control treatments during the rearing period $(\mathrm{P}<0.05)$. Also, the significant difference of $\mathrm{Pb}$ concentration in liver of $4 \%$ DPS extract treatment was found compared to $0.5 \%$, $1 \%$, and $2 \%$ DPS extract and control treatments $(\mathrm{P}<0.05)$.

$\mathrm{Cd}$ concentrations in muscle of fish decreased in $0.5 \%$, $1 \%, 2 \%$, and $4 \%$ of DPS extract, and in liver decreased in $1 \%$ and $0.5 \%$ DPS extract. Cd concentrations in liver of $2 \%$ and 4\% DPS extract increased in comparison with other treatments. Significant differences of Cd concentrations in muscle of $0.5 \%, 1 \%, 2 \%$, and $4 \%$ DPS extract were observed compared to $0 \%$ (control) treatment during the rearing period $(\mathrm{P}<0.05)$. Significant differences of $\mathrm{Cd}$ concentrations in liver of $1 \%$ DPS extract were found compared to $0 \%$ (control), $0.5 \%, 2 \%$, and $4 \%$ treatments $(\mathrm{P}<0.05)$.

As concentrations in muscle decreased in $0.5 \%, 1 \%$, and $2 \%$ of DPS extract, and in liver decreased in $0.5 \%$ and $1 \%$ DPS extract. As concentrations in muscle and liver of 4\% DPS extract increased in comparison with other treatments. Also, As concentrations in liver of $2 \%$ DPS extract increased in comparison with other treatments, which was similar to $4 \%$ DPS extract. Significant differences of As concentrations in muscle 
Table 2. Heavy metals concentrations ( $\mathrm{mg} / \mathrm{kg}$ ) in fish muscle and liver of zero phase, control, and four additional date palm (Phoenix dactylifera) seed (DPS) extract treatments during 60 days of rearing.

\begin{tabular}{|c|c|c|c|c|}
\hline Heavy metals & $\mathrm{Pb}$ & $\mathrm{Cd}$ & As & $\mathrm{Hg}$ \\
\hline \multicolumn{5}{|c|}{ Muscle (mg/kg) } \\
\hline Zero phase & $0.0122 \pm 0.0031^{\mathrm{b}}$ & $0.0036 \pm 0.0006^{\mathrm{a}}$ & $0.0285 \pm 0.0086^{\mathrm{d}, \mathrm{e}}$ & $0.0183 \pm 0.0020^{\mathrm{a}}$ \\
\hline Control & $0.0254 \pm 0.0033^{\mathrm{ab}}$ & $0.0039 \pm 0.0004^{\mathrm{a}}$ & $0.0691 \pm 0.0048^{\mathrm{b}}$ & $0.0151 \pm 0.0023^{\mathrm{a}}$ \\
\hline $0.5 \%$ & $0.0168 \pm 0.0090^{\mathrm{b}}$ & $0.0020 \pm 0.0009^{\mathrm{b}}$ & $0.0240 \pm 0.0067^{\mathrm{e}}$ & $0.0045 \pm 0.0009^{b}$ \\
\hline $1 \%$ & $0.0195 \pm 0.0095^{\mathrm{ab}}$ & $0.0020 \pm 0.0005^{\mathrm{b}}$ & $0.0403 \pm 0.0007^{\mathrm{d}}$ & $0.0025 \pm 0.0019^{b}$ \\
\hline $2 \%$ & $0.0348 \pm 0.0236^{\mathrm{ab}}$ & $0.0021 \pm 0.0001^{\mathrm{b}}$ & $0.0546 \pm 0.0062^{\mathrm{c}}$ & $0.0040 \pm 0.0012^{\mathrm{b}}$ \\
\hline $4 \%$ & $0.0415 \pm 0.0118^{\mathrm{a}}$ & $0.0028 \pm 0.0012^{\mathrm{ab}}$ & $0.0988 \pm 0.0115^{\mathrm{a}}$ & $0.0082 \pm 0.0060^{\mathrm{b}}$ \\
\hline \multicolumn{5}{|c|}{ Liver (mg/kg) } \\
\hline Zero phase & $0.0431 \pm 0.0063^{b}$ & $0.0143 \pm 0.0090^{\mathrm{ab}}$ & $0.0956 \pm 0.0180^{c}$ & $0.0043 \pm 0.0007^{\mathrm{b}}$ \\
\hline Control & $0.2984 \pm 0.1337^{\mathrm{ab}}$ & $0.0240 \pm 0.0025^{\mathrm{a}}$ & $0.2061 \pm 0.0770^{\mathrm{b}, \mathrm{c}}$ & $0.0083 \pm 0.0013^{\mathrm{a}}$ \\
\hline $0.5 \%$ & $0.0268 \pm 0.0060^{\mathrm{b}}$ & $0.0212 \pm 0.0045^{\mathrm{a}}$ & $0.1283 \pm 0.0657^{\mathrm{c}}$ & $0.0061 \pm 0.0005^{\mathrm{b}}$ \\
\hline $1 \%$ & $0.0357 \pm 0.0081^{\mathrm{b}}$ & $0.0058 \pm 0.0016^{\mathrm{b}}$ & $0.1567 \pm 0.0578^{\mathrm{b}, \mathrm{c}}$ & $0.0051 \pm 0.0006^{\mathrm{b}}$ \\
\hline $2 \%$ & $0.0329 \pm 0.0075^{b}$ & $0.0271 \pm 0.0026^{\mathrm{a}}$ & $0.2683 \pm 0.0497^{b}$ & $0.0083 \pm 0.0016^{\mathrm{a}}$ \\
\hline $4 \%$ & $0.6337 \pm 0.4004^{\mathrm{a}}$ & $0.0241 \pm 0.0132^{\mathrm{a}}$ & $0.4464 \pm 0.0898^{\mathrm{a}}$ & $0.0003 \pm 0.0002^{\mathrm{c}}$ \\
\hline
\end{tabular}

All values are expressed as the means \pm SD with Tukey test. Numerals refer to significant differences of heavy metals concentrations $(\mathrm{mg} / \mathrm{kg})$ at each date palm (Phoenix dactylifera) seed (DPS) extract treatment $(\mathrm{P}<0.05)$ with: zero phase, control, $0.5 \%$ treatment, $1 \%$ treatment, $2 \%$ treatment, and $4 \%$ treatment.

of all experimental treatments were observed during the rearing period $(\mathrm{P}<0.05)$. Significant differences of As concentrations in liver were found between $2 \%$ and $4 \%$ with $0.5 \%$ and $1 \%$ DPS extract $(\mathrm{P}<0.05)$.

$\mathrm{Hg}$ concentrations in muscle decreased in $1 \%, 2 \%$, $0.5 \%$, and $4 \%$ of DPS extract, and in liver decreased in $4 \%, 1 \%$, and $0.5 \%$ DPS extract. Hg concentrations in liver of fish fed the $2 \%$ DPS extract increased in comparison with other treatments. Significant differences of $\mathrm{Hg}$ concentrations in muscle of $0.5 \%, 1 \%, 2 \%$, and $4 \%$ DPS extract were observed compared to $0 \%$ (control) treatment during the rearing period $(\mathrm{P}<0.05)$. Significant differences of $\mathrm{Hg}$ concentrations in liver of $0.5 \%, 1 \%$, and $4 \%$ DPS extract were found compared to $0 \%$ (control) treatment $(\mathrm{P}<0.05)$. Also, significant differences in $\mathrm{Hg}$ concentration in liver of $2 \%$ DPS extract was found compared to $0.5 \%$, $1 \%$, and $4 \%$ DPS extract $(\mathrm{P}<0.05$; Table 2$)$.

Heavy metals concentrations of fish decreased in the $0.5 \%$ and $1 \%$ treatments. In the $2 \%$ treatment the concentrations of heavy metals were increased in liver, except for $\mathrm{Pb}$ metal. Also, heavy metals concentrations in this treatment decreased in the muscle, except for $\mathrm{Pb}$ accumulation in muscle. Heavy metals concentrations in muscle and liver increased in the $4 \%$ treatments except for $\mathrm{Cd}$ concentrations in muscle and $\mathrm{Hg}$ concentrations in muscle and liver - particularly liver, in which $4 \%$ DPS extract dose of the diet could decrease $\mathrm{Hg}$ rather than other doses $(\mathrm{P}<0.05)$. Also, $\mathrm{Hg}$ and $\mathrm{Cd}$ concentrations in muscle decreased in all treatments. The present study describes findings that are essential for future studies in decreasing toxic metals of common carp (Cyprinus carpio) by date palm (Phoenix dactylifera) seed (DPS) extract.

\section{Phytochemical Analysis of DPS Extract Compounds}

Our results of phytochemical analysis on phenolic profile of date palm seed (DPS) extract were: gallic, protocatechuic, p-hydroxybenzoic, vanillic, caffeic, ferulic, p-coumaric, m-coumaric, o-coumaric, quercitin, sinapic, cinnamic, and 5-o-caffeoylshikimic acids.

This is in agreement with Al-Farsi and Lee [14], who detected phenolic acids in date seeds, including: gallic, protocatechuic, p-hydroxybenzoic, vanillic, caffeic, p-coumaric, ferulic, m-coumaric, and o-coumaric acids. Also, Ammar et al. [15] reported similar results for phytochemicals on seed of the plant. Moreover, Mansouri et al. [16] analyzed the phenolic profiles of seven Algerian varieties of date and observed that they contain p-coumaric, ferulic, and sinapic acids, some cinnamic acid derivatives, and three different isomers of 5-o-caffeoyl shikimic acid.

Determining the polyphenolic profile is of great importance in terms of future potential value of date seeds as a functional ingredient protecting against heavy metal toxicity [17]. Phenolics and flavonoids have multiple protective functions such as antioxidative activity. Therefore, they have also been discussed as protectants against heavy metal stress [18]. 


\section{Effects of Plant Extracts on Heavy Metals Toxicity}

The selected studies on the protective effects of plant extracts against heavy metals toxicity in male rats includes:

- Ginger (Zingiber officinale) (2011): administered form $(150 \mathrm{mg} / \mathrm{kg}$ body weight ginger extract by oral gavage), duration (three weeks), animal model (male rats exposed to $300 \mathrm{mg} / \mathrm{kg}$ body weight $\mathrm{Pb}$-nitrate by oral gavage), target sites (kidneys), protective effects (ginger recovered the GSH level and the activity of antioxidant enzymes and alleviated renal histological changes) [19]

- Green tea (2012): administered form $(1.5 \% \mathrm{w} / \mathrm{v}$ green tea extract in drinking water), duration (eight weeks), animal model (male rats exposed to $0.4 \% \mathrm{~Pb}$-acetate in drinking water), target sites (liver), protective effects (green tea recovered hepatic function and alleviated histological changes in the liver) [20]

- Curry leaf (Murraya koenigii) (2012): administered form $(100 \mathrm{mg} / \mathrm{kg}$ body weight curry leaf extract orally), duration (15 days), animal model (male rats exposed to $0.44 \mathrm{mg} / \mathrm{kg}$ body weight $\mathrm{CdCl} 2$ subcutaneously), target sites (heart), protective effects (curry leaf increased the activity of cardiac antioxidant enzymes and decreased the cardiac lipid peroxidation and Cd levels) [21]

This research is the first report to our knowledge demonstrating the effect of DPS extract on decreased heavy metals concentrations in muscle and liver of fish because of bioactive polyphenol compounds of DPS extract inhibiting heavy metals transport across the enterocyte and liver to fish body by a chelating mechanism.

On the other hand, it is important to note that the information shown here provides an overview of the conditions that determine the concentrations of $\mathrm{Pb}, \mathrm{Cd}$, As, and $\mathrm{Hg}$ in muscle and liver of common carp before applying DPS extract to diet. The results revealed that heavy metals concentrations $(\mathrm{mg} / \mathrm{kg}$ wet weight) in fish muscle and liver of zero phase were $\mathrm{Pb}-\mathrm{M}$ : $0.0122 \pm 0.0031$, $\mathrm{Pb}-\mathrm{L}: \quad 0.0431 \pm 0.0063, \quad \mathrm{Cd}-\mathrm{M}: \quad 0.0036 \pm 0.0006, \quad \mathrm{Cd}-$ L: $\quad 0.0143 \pm 0.0090, \quad$ As-M: $0.0285 \pm 0.0086$, As-L: $0.0956 \pm 0.0180$, Hg-M: $0.0183 \pm 0.0020$, and Hg-L: $0.0043 \pm 0.0007$. According to research, the results showed different levels of heavy metals concentrations $(\mathrm{mg} / \mathrm{kg})$ in tissues of common carp (Cyprinus carpio) as: muscle (Cd: $0.13 \pm 0.10, \mathrm{~Pb}: 1.98 \pm 1.61)$, liver $(\mathrm{Cd}: 0.06 \pm 0.05$, $\mathrm{Pb}: 2.79 \pm 0.29)$ [22], muscle (Cd: $0.009 \pm 0.005, \mathrm{~Pb}$ : $0.081 \pm 0.002)$ [23], and range (min-max) of $\mathrm{Cd}, \mathrm{Hg}$, and As in muscle (Cd: 0.044-0.093, Hg: 0.03-0.11, As: 0.0040.006 ) [24], muscle (Cd: $0.003 \pm 0.001, \mathrm{Hg}: 0.06 \pm 0.02$ ), and liver (Cd: $0.004 \pm 0.001)$ [25]. In contrast, research about concentrations of heavy metals in tissues of carp showed different levels of heavy metals concentrations in fish, which indicates using DPS extract as a food and drug supplement in the diet of fish.

The medicinal use of extracts prepared from date plants is an ancient practice. Furthermore, it has been proposed that its antioxidant constituents account for its beneficial therapeutic effects. Dates have phenolic compounds (mainly cinnamic acids) and flavonoids (flavones, flavonols, and flavanones) that provide antioxidant activities [26].

\section{Effects of DPS Extract on Heavy Metals Toxicity of Fish}

Metal contamination of the aquatic environment is a long-term issue, since metals accumulate in aquatic organisms, including fish. Fish are an important source of metals in human nutrition, and those from metal-contaminated sites present a potential risk to human health [27]. According to the mechanisms of absorption, regulation, storage, and excretion of metals, the various fish tissues present varying bioaccumulation rates [28].

Generally, gills, kidney, liver, and muscles are the main ways of attracting metal ions into the bodies of fish [29]. According to the literature, metal bioaccumulation by fish and subsequent distribution in organs is greatly interspecific. In addition, many factors can influence metal uptake, like physiological mechanisms, feeding behavior, metabolism, swimming patterns, and chemical characteristics of water [29]. Fish liver exhibited the highest tendency to accumulate heavy metals and - as well as the low accumulation of heavy metals in muscle - may be due to low levels of metal-binding proteins in muscles [30]. It seems that muscle is not seen as the main location of heavy metals accumulation [31].

Polyphenolic and flavonoid compounds of plant extracts exhibited the highest tendency to bind with heavy metals in the gastrointestinal tract of fish due to strong associated cluster-network structures that may increase the fraction of unabsorbed heavy metals and overall fecal excretion. Enhance fecal excretion is the sum of heavy metals excreted from the body plus unabsorbed heavy metals $[32,33]$. So, polyphenolic and flavonoid compounds of DPS extract can remove heavy metals via metal-chelating in the gastrointestinal tract of fish and prevent muscles from transferring and absorbing heavy metals.

Organisms have developed various strategies to protect themselves against the adverse effects of ions and their compounds that come from metals exposure of the biosphere. In animals, metallothioneins (MT) play a key role in maintaining metal homeostasis. Metallothioneins are a group of low molecular mass ( 2 to $16 \mathrm{kDa}$ ) singlechain proteins. The metal binding domain of MTs consists of 20 cysteine residues juxtaposed with basic amino acids (lysine and arginine) arranged in two thiol-rich sites [34]. Based on their affinity to metals these proteins are able to transport essential metals to a place of need or detoxify toxic metals to protect cells [35]. Two isoforms of MT, MT-1 and MT-2, are described in all vertebrates, including fish [36]. In fish the relationship between MTs and metals was mainly demonstrated in the case of binding both physiological (such as zinc, copper, selenium) and xenobiotic (such as cadmium, mercury, lead, arsenic, silver) metals [37]. 
Metallothionein synthesis in fish is associated with organs involved in metal uptake and metabolism, such as liver and kidney [38].

Polyphenolic and flavonoid compounds of plant extract increase metallothionein synthesis in the liver and improve metallothionein action to chelate heavy metals [38, 39].

The antioxidant action of phenolic compounds of plant extracts is due to their high tendency to chelate heavy metals. This general chelating ability of phenolic compounds is probably related to the high nucleophilic character of the aromatic rings rather than to specific chelating groups within the molecule [40]. There is another mechanism underlying their antioxidant ability. Metal ions decompose lipid hydroperoxide (LOOH) by the hemolytic cleavage of the $\mathrm{O}-\mathrm{O}$ binding and give lipid alkoxyl radicals, which initiate free radical chain oxidation. Phenolic antioxidants inhibit lipid peroxidation by trapping the lipid alkoxyl radical. This activity depends on the structure of the molecules, and the number and position of the hydroxyl group in the molecules [39].

Although, fish liver exhibited the highest tendency to accumulate heavy metals, polyphenolic and flavonoid compounds of DPS extract have a high tendency to chelate metals. Also, these compounds increase metallothionein synthesis in the liver and improve metallothionein action to chelate heavy metals. Phenolic antioxidants inhibit lipid peroxidation by trapping the lipid alkoxyl radical. So, it removes heavy metals from liver and prevents the transfer and absorption of heavy metals in the fish body.

The results presented here demonstrate that additional DPS extract at $0.5 \%$ and $1 \%$ doses in fish diet clearly reduce the concentrations of heavy metals in fish. The results of this research clearly show that the effects of adding DPS extract in fish diet are significant $(\mathrm{P}<0.05)$. We suggest that DPS extract might be added to diets just prior to feeding in future research to further reduce heavy metals concentrations in fish.

\section{Conclusions}

The present study has described findings that are essential for future studies to decrease toxic metals by DPS extract. In this study, the results demonstrate that additional DPS extract in fish diets clearly reduce the concentrations of heavy metals at $0.5 \%$ and $1 \%$ doses in fish. Phenolics and flavonoid compounds of DPS extract have multiple protective functions such as antioxidative activity and protectants against heavy metal stress. They can remove heavy metals in the gastrointestinal tract and liver via metal-chelating, increase metallothionein synthesis in the liver, and inhibit lipid peroxidation by trapping the lipid alkoxyl radical that can remove heavy metals and prevent them from absorbing heavy metals in the fish body. We suggest that DPS extract might be added to diets just prior to feeding in future research to further reduce heavy metals concentrations in fish.

\section{Acknowledgements}

The authors would like to acknowledge the Medicinal Plants and Natural Products Research Center, Ahvaz Jundishapur University of Medical Sciences, the Department of Aquatic Animal Health, Faculty of Veterinary Medicine, University of Tehran, and the Food and Drug Organization, Tehran.

\section{References}

1. KIM N.S., LEE B.K. Blood total mercury and fish consumption in the Korean general population in KNHANES III, 2005. Sci. Total Environ. 408, 4841, 2010.

2. SARMIENTO A.M., DELVALLS A., MIGUEL NIETO J., SALAMANCA M.J. CARABALLO, M.A. Toxicity and potential risk assessment of a river polluted by acid mine drainage in the Iberian Pyrite Belt (SW Spain). Sci. Total. Environ. 409 (22), 4763, 2011.

3. BESBES S., BLECKER C., DEROANNE C., DRIRA N.E. ATTIA H. Date seeds: chemical composition and characteristic profiles of the lipid fraction. Food Chem. 84, 577, 2004.

4. AL FARSI M.A., ALASALVAR C., MORRIS A., BARON M., SHAHIDI F. Comparison of antioxidant activity, anthocyanins, carotenoids, and phenolics of three native fresh and sun-dried date Phoenix dactylifera L.) varieties grown in Oman. J. Agric. Food. Chem. 53, 7592, 2005.

5. HABIB H.M., PLATAT C., MEUDEC E., CHEYNIER V., IBRAHIM W.H. Polyphenolic compounds in date fruit seed (Phoenix dactylifera): characterisation and quantification by using UPLC-DAD-ESI-MS. J. Sci. Food Agri. 94 (6), 1084, 2014.

6. SOONG Y., BARLOW P.J. Antioxidant activity and phenolic content of selected fruit seeds. Food Chem. 88, 411, 2004.

7. SWANSON D., BLOCK R., MOUSA S.A. Omega-3 fatty acids EPA and DHA: health benefits throughout life. Adv. Nutr. 3 (1), 1, 2012.

8. MARTORELL I., PERELLó G., MARTí-CID R., LLOBET J.M., CASTELL V., DOMINGO J. L. Human exposure to arsenic, cadmium, mercury, and lead from foods in Catalonia, Spain: temporal trend. Biol. Trace Elem. Res. 14 (3), 309, 2011.

9. AOAC. Official Methods of Analysis of AOAC INTERNATIONAL, $19^{\text {th }}$ Edition. 2012.

10. BOLIGON A.A., ATHAYDE M.L. Importance of HPLC in Analysis of Plants Extracts. Austin Chromatogr. 1 (3), 1, 2014.

11. OLMEDO P., PLA A., HERNANDEZ A.F., BARBIER F., AYOUNI L., GIL F. Determination of toxic elements (mercury, cadmium, lead, tin and arsenic) in fish and shellfish samples. Risk assessment for the consumers. Environ. Int. 59, 63, 2013.

12. RStudio and Inc. shiny. Web Application Framework for R. $\mathrm{R}$ package version 0.5.0. 2013.

13. HABIB H., KAMAL H., IBRAHIM W., AL DHAHERI A.S. Carotenoids, fat soluble vitamins and fatty acid profiles of 18 varieties of date seed oil. Indust. Crops. Products. 42, 567, 2013.

14. AL FARSI M.A., LEE C.Y. Nutritional and functional properties of dates. Crit. Rev. Food Sci. Nutr. 48, 877, 2008.

15. AMMAR N.M., AL-OKBI S.Y., MOHAMED D.A., ELKASSEM L.T.A. Antioxidant and Estrogen like Activity of 
the Seed Phoenix dactylifera L. Palm growing in Egyptian Oases. Sci. pub. 1 (3), 1, 2009.

16. MANSOURI A., EMBAREK G., KOKKALOUC E., KEFALAS P. Phenolic profile and antioxidant activity of the Algerian ripe date palm fruit (Phoenix dactylifera). Food Chem. 89, 411, 2005.

17. MANACH C., WILLIAMSON G., MORAND C., SCALBERT A., REMESY C. Bioavailability and bioefficacy of polyphenols in humans. I. Review of 97 bioavailability studies. Am. J. Clin. Nutr. 81, 230, 2005.

18. RUSAK G., GUTZEIT H., LUDWIG-MŪLLER J. Structurally related flavonoids with antioxidative properties differentially affect cell cycle progression and apoptosis of human acute leukemia cells. Nutr. Res. 25, 143, 2005.

19. REDDY Y.A., CHALAMAIAH M., RAMESH B., BALAJI G., INDIRA P. Ameliorating activity of ginger (Zingiber officinale) extract against lead induced renal toxicity in male rats. J. Food Sci. Technol. 1, 1, 2011.

20. MEHANA E., MEKI A.R., FAZILI K.M. Ameliorated effects of green tea extract on lead induced liver toxicity in rats. Exp. Toxicol. Pathol. 64, 291, 2012.

21. MITRA E., GHOSH A.K., GHOSH D., MUKHERJEE D., CHATTOPADHYAY A., DUTTA S., PATTARI S.K., BANDYOPADHYAY D. Protective effect of aqueous Curry leaf (Murraya koenigii) extract against cadmium-induced oxidative stress in rat heart. Food Chem. Toxicol. 50, 1340, 2012.

22. DERRAG Z., DALI YOUCEF N., MESLI L. Seasonal Variations Of Heavy Metals In Common Carp (CyprinusCarpio L., 1758) Collected From Sikkak Dam Of Tlemcen (Algeria). J. Engin. Res. Appli. 4 (1), 1, 2014.

23. OGENDI G.M., MAINA G.M., MBUTHIA J.W., KOECH H.K., RATEMO C.M., KOSKEY J.C. Heavy Metal Concentrations in Water, Sediments and Common Carp (Cyprinus carpio) Fish Species from Lake Naivasha, Kenya. Res. J. Environ. Earth Sci. 6 (8), 416, 2014.

24. SOBHANARDAKANI S., JAFARIB S.M. Heavy metals contamination in silver, common and grass carp caught from Zarivar Lake, western Iran. Europe. Online J. Natur. Soc. Sci. 3 (2), 344, 2014.

25. SOBHANARDAKANI S., JAFARI S.M. Metals Analysis in common carp (Cyprinus carpio) from Shirinsu Wetland, Hamedan province, Iran. Arch. Hyg. Sci. 4 (4), 172, 2015.

26. 2AL-ORF S.M., AHMED M.H.M., AL-ATWAI N., ALZAIDI H., DEHWAH A., DEHWAH S. Review: Nutritional Properties and Benefits of the Date Fruits (Phoenix dactylifera L.). Bull. Nation. Nutri. Instit Arab Repub. Egypt. 39, 97, 2012.

27. FLEEGER J.W., CARMAN K.R., NISBET R.M. Indirect effects of contaminants in aquatic ecosystems. Sci. Total Environ. 317 (1), 207, 2003.

28. STORELLI M.M., CUTTONE G., MARCOTRIGIANO, G.O. Distribution of trace elements in the tissues of smooth hound Mustelus mustelus (Linnaeus, 1758) from the southern-eastern waters of Mediterranean Sea (Italy). J. Environ. Monit. Assess. 174 (1-4), 271, 2011.

29. ZHAO S., FENG C., QUAN W., CHEN X., NIU J., SHEN Z. Role of living environments in the accumulation characteristics of heavy metals in fishes and crabs in the Yangtze River Estuary, China. Mar. Pollut. Bull. 64, 1163, 2012.

30. ALLEN-GILL S.M., MARTYNOV V.G. Heavy metals burdens in nine species of freshwater and anadromous fish from the Pechora River, Northern Russia. Sci. Total Environ. 160-161, 653, 1995.

31. ROMEO M., SIAU Y., SIDOUMOU Z., GNASSIABARELLI M. Heavy metal distribution in different fish species from the Mauritania coast. Sci. Total Environ. 232, 169, 1999.

32. BERNTSSEN M.H.G., HYLLAND K., LUNDEBYE A.K., JULSHAMN K. Higher faecal excretion and lower tissue accumulation of mercury in Wistar rats from contaminated fish than from methylmercury chloride added to fish. Food Chem. Toxicol. 42, 1359, 2004.

33. MICHALAK A. Phenolic Compounds and Their Antioxidant Activity in Plants Growing under Heavy Metal Stress. Polish J. Environ. Stud. 15 (4), 523, 2006.

34. ECKSCHLAGER T., ADAM V., HRABETA J., FIGOVA K., KIZEK R. Metallothioneins and cancer. Curr. Protein Pept. Sci.10 (4), 360, 2009.

35. HISPARD F., SCHULER D., DE VAUFLEURY A., SCHEIFLER R., BADOT P.M., DALLINGER R. Metal distribution and metallothionein induction after cadmium exposure in the terrestrial snail Helix aspersa (Gastropoda, Pulmonata). Environ. Toxicol. Chem. 27 (7), 1533, 2008.

36. VASAK M., HASLER D.W. Metallothioneins: new functional and structural insights. Curr. Opin. Chem. Biol. 4 (2), 177, 2000.

37. BEBIANNO M.J., SANTOS C., CANARIO J., GOUVEIA N., SENA-CARVALHO D., VALE C. Hg and metallothionein-like proteins in the black scabbardfish Aphanopus carbo. Food Chem. Toxicol. 45 (8), 1443, 2007.

38. FALFUSHYNSKA H.I., STOLIAR O.B. Function of metallothioneins in carp (Cyprinus carpio) from two field sites in Western Ukraine. Ecotox. Environ. Safe.72 (5), 1425, 2009.

39. MILLIC B.L., DJILAS S.M., CANADANOVIC-BRUNET J.M. Antioxidative activity of phenolic compounds on the metal-ion breakdown of lipid peroxidation system. Food Chem. 61, 443, 1998.

40. MORGAN J.F., KLUCAS R.V., GRAY ER R.J., ABIAN J., BECANA M. Complexes of iron with phenolic compounds from soybean nodules and other legume tissues: prooxidant and antioxidant properties. Free Radic. Biol. Med. 22, 861, 1997. 